\title{
Monks and businessmen in Catalonia: the Benedictines of Montserrat (1900-1936) ${ }^{1}$
}

Fco. Javier Fernández-Roca

\section{Introduction.}

The history of Spain cannot be understood without the presence of the Catholic Church, even though the preponderant role of this institution gradually decayed, more slowly during the $19^{\text {th }}$ century and in a more accelerated way during the $20^{\text {th }}$ century. Nevertheless, its accumulated decline did not prevent the Catholic Church from continuing to be, together with the army, one of the most relevant institutions in the country. However, it had to learn to cope with the new game rules fostered by liberal revolutions. In the time between the first third of the $19^{\text {th }}$ century and the first third of the $20^{\text {th }}$ century, a Catholic basis deeply rooted in the social body of the nation coexisted with anti-clerical currents that ranged from those trying to separate the Church from the State - hoping to clearly delimit the role and pre-eminence of the civil power - to those, deeply anti-religious, which prevailed during the Second Republic and the later Civil War.

With such social division, the history of Spain between 1833 and 1936 was a constant pendulum-like motion between pro-clerical and anti-clerical governments. The 1830s witnessed several ecclesiastical confiscations, the abolition of monasteries, the uncloistering of the members of religious orders and the expulsion of the Society of Jesus. The Isabeline period (1844-1868) followed, and the different orders and congregations were allowed to return to Spain while the Church was able to recover from its losses. The 1868 Revolution marked the end of that period, bringing new expulsions, abolitions and uncloistering decrees. The Restoration and the Dictatorship of General Primo de Rivera (1874-1931) represented the longest period of stability in Spain along that century and meant the definitive establishment of religious orders in the country and the economic and social recovery of the Catholic Church. Later on, the 
Second Republic again released the anti-clerical forces and opened a new period of unrest for the Church.

During the last third of the 19th century, the Spanish Church had accumulated enough negative experiences as to mistrust an ever uncertain future in the face of the political swings in Spain and it took advantage of the stability provided during the Restoration period to adopt certain defensive strategies. In the course of those final years of the century, some religious orders had learnt that they had to be efficient in concealing their properties - or at least part of them - from the eyes of the political power if they wanted to survive and avoid possible future confiscation processes, undertaken by a State they did not trust. ${ }^{2}$ Historiography shows an enormous gap in what concerns regular orders, research having been focused almost exclusively on the legal and political aspects of the relationship between the State and the Church and between society and the Church, or in deepening the knowledge of ecclesiastical hierarchy and secular clergy. ${ }^{3}$ A relevant number of authors point to the existence of a research gap regarding regular orders, of which very little is known except for minimal contributions on the Jesuits. ${ }^{4}$ References on the patrimony of regular orders are still barely anything else than general comments. For instance, García de Cortázar speaks of “el vertiginoso enriquecimiento de algunas instituciones religiosas" (“the extremely rapid enrichment of certain religious institutions”), although he offers little specific information on it; Domínguez Ortiz states that the reconstruction of the regular orders with thousands of members together with the buildings that accommodated them "no pudo hacerse sin una adecuada infraestructura material, pero sobre este punto se extiende un espeso manto de silencio" ("could not be made without the adequate material infrastructure, but on this matter a thick silent cover is extended"); Palomares refers to the "respaldo 
indispensable para sostener estas obras" ("the indispensable backing to support those works"). ${ }^{5}$ On this issue, Cárcel clarifies the magnitude of the regular orders’ wealth by opposing the theoretical value of their urban properties with their profitability, then subtracting the cost of their maintenance, and he concludes that the orders were selflessly devoted to teaching since, if their properties "se hubiesen vendido, el dinero, bien invertido, hubiera rentado mucho más, y sin ningún trabajo, del que dejaba su dedicación a la docencia" ("had been sold, the money, wellinvested, would have effortlessly rendered much higher profits than those obtained through their teaching activities”). ${ }^{6}$ Callahan specifies that, considering the lack of "trustable" information, we are most probably unable to know if the religious orders indeed accumulated a great patrimony. We can agree with García de Cortázar on that some masculine orders "se convirtieron en expertas en el uso de métodos capitalistas" ("became experts in the use of capitalistic methods"), but convincing proofs of that behaviour are still missing. ${ }^{7}$

With this article we aim to contribute to the occupation of a portion of the little explored historiographical field dealing with the history of religious orders. Our work explains how the Benedictines of the Monastery of Montserrat adopted the appropriate strategies to conceal their patrimony from the State. The tool that they used - not new for it had already been employed by the Society of Jesus - was the creation of a front organisation under the legal figure of a public limited company. If our example was just that of a public limited company that acted only as a fake holder of the Community's properties it would not require our effort, since many similar cases have already been discussed. ${ }^{8}$ However, the behaviour of the Benedictine monks at Montserrat is singular enough to be considered apart from the usual pattern and it certainly deserves a detailed treatment. There are three facts that make of the 
Benedictine public limited company a remarkable case. First, its longevity, since the company was created in 1913 and, almost one century afterwards, it is still functioning - the only case known in this category in Spain. Second, the public limited company in Montserrat was more opaque and therefore more successful than those created by other religious orders when trying to cover up their properties and guarantee the well-being of the Community. Third, the firm was more than just a mechanism to conceal the Community's assets; it became a modernizing tool in the management of its properties and businesses.

The originality of the case lies in that it studies a firm, a public limited company, whose hidden owners are members of a religious order, and, confronted with this evidence, we may ask ourselves if the company's management was different from that of other organisations whose owners were laymen. The Benedictine company developed a double instrumental function: one, it modestly increased the Community's patrimony and, two, it improved the use of the properties and the management of the services offered by the monks to the pilgrims arriving to the Monastery. The singular aspect is precisely that the public limited company was transformed from its purely defensive origin - to avoid the confiscation of the Community's estate - into a business management tool. The Benedictines converted the company into a mechanism to fulfil their interests. If longevity and solvency were at the beginning the primary objectives so as to preserve the patrimony, during the period of the Second Republic maximizing the profits and increasing liquidity soon became the main focus. Finally, from a Business History perspective we analyse how the Benedictine Community at Montserrat, without actually being conscious of its actions, chose to externalise the management of its services and properties by creating a company. This company was legally independent from the Community and it improved the management of the Community's patrimony 
by adapting it to less paternalistic parameters and by implementing conservative strategies on it. ${ }^{9}$

The article is divided into four sections. In the first one, we briefly review the history of the Catholic Church in Spain from the end of the absolutist reign of Ferdinand VII (1833), along the tortuous path of the establishment of liberalism in Spain, to the outbreak of the Civil War (1936). The second section looks into the origin of the Benedictine public limited company, from its precedents, when Abbot Deàs took an interest in avoiding future governmental confiscations of the Community's properties, to the actual foundation of the company at the time when Marcet held the position of ruling abbot. The third section describes the concealing strategies implemented by the Benedictine Community, first on their rural properties and, years afterwards, on both the buildings surrounding the Monastery and the management of the services offered to the pilgrims in them. This way, the company became more than just an interposed society that served to hide Benedictine properties away from the State; it became a tool to manage the Community's businesses. Finally, in the fourth section we analyse the business strategies implemented by the company's Administration Board, which can be defined as financial solidity, low level of indebtedness and "organic" growth. We also analyse the change brought by the establishment of the Second Republic, which was aggravated in 1934, when the Community forced the company's functioning aiming to achieve greater liquidity for the Monastery.

\section{The development of the Spanish Catholic Church during the 19th century (1833-} 1936).

Scientific literature has established a six-phase chronological framing of the evolution of religious orders in Spain. ${ }^{\mathbf{1 0}}$ Regarding the history of the Church, the period that created greater controversy, and the one more thoroughly attended to, is that which 
stretches from 1833 to 1843 . On that period, events such as the establishment of liberalism (Martínez de la Rosa, 1833-1834), ecclesiastical confiscations (Toreno and Mendizábal, 1835-1840) and the Regency (Espartero, 1840-1843) followed each other, and at the end of it the Ancient Regime Church had been dismantled. ${ }^{11}$ Spanish liberalism, like the coetaneous Latin American liberalism, saw the Catholic Church as the bastion of reactionary forces, responsible for the population's fanaticism and illiteracy. Thus, the Liberals planned the battle against the Church having in mind three main issues: the clergy's legal privileges, which they aimed to abolish, the appointment of bishops and the wealth of the Church. Regarding this last issue, the Liberals understood that the State had to take over the Church's tithes, real estate and invested capitals in order to remove the obstacles that hindered economic progress. The liberal State not only contemplates the appropriation of diocesan assets but especially of those assets belonging to regular orders, which were denounced as useless, unproductive and dangerous due to their popular acceptance. ${ }^{12}$

In the specific case of Spain, the confiscation of the real estate of the Church was undertaken during the governments of Toreno and Mendizábal. ${ }^{13}$ Gradually, laws were passed that led to the expulsion of the Society of Jesus and to the confiscation of its properties (1835), the abolition of convents and monasteries with less than 12 members (1835), the sale of the assets seized from the abolished religious communities (1836) and the uncloistering of their members (1836), in a process that suppressed "Ios monasterios, conventos, colegios, congregaciones y demás casas de comunidad o de instituciones religiosas de varones, incluso las de clérigos regulares y las de las cuatro órdenes militares” (“monasteries, convents, schools, congregations and other community houses belonging to masculine religious institutions, including those of the regular clergy and the four military orders”). ${ }^{14}$ 
The years between 1843 and 1874, the second phase in our scheme, include one of the usual comings and goings in Spanish history: one pro-clerical period, under the reign of Isabella II (1843-1868), was followed by another deeply anti-clerical reaction during the Democratic Six Years Period (1868-1874). During the reign of Isabella II, religious orders gradually returned to Spain under the protection of the 1845 Constitution, which declared, in its article 11, the Catholic religion to be that of the Spanish nation and made the State assume the monetary commitment to support the secular clergy and maintain the worship. At the beginning of this reign, the sale of ecclesiastical properties was suspended, the assets that had not been transferred were given back to the secular (not the regular) clergy, exiled bishops returned to Spain, the Tribunal of the Roman Rota was re-established and the process of uncloistering reversed. A few years later, the 1851 Concordat legally restored the orders, the Church's control of education and its right to own assets. ${ }^{15}$ During the "Moderate Decade” (1844-1854), the episcopacy and the clergy were focused in the vast works of reconstruction and administrative and catechist reorganisation. ${ }^{16}$ Generally speaking, the Isabeline reign was a pro-clerical period to the point that the Spanish Church became the last defensive bastion of the Isabeline monarchy, thus adopting a political role that distinguished the Spanish institution from the French-Belgian and Central European Churches, devoted to cultural and social-economic issues. ${ }^{17}$

The second part of this phase started with the 1868 Revolution and the provisional government of 1869-1870, and it continued with the short reign of Amadeo I of Savoy (November 1870 to February 1873) and the later proclamation of the ephemeral First Republic (February 1873 to January 1874), which meant the rise to power of the most progressive social groups, both democratic and republican, all of them strongly anti-clerical. ${ }^{18}$ The main measures adopted by the revolutionary 
government were those typical of Spanish anti-clericalism: abolition of the Society of Jesus, prohibition of community meetings, freedom of teaching, freedom of worship, inhibition of the religious orders from acquiring or possessing assets, extinction of all the communities founded after 1837, etc. ${ }^{19}$ However, the government's inoperative performance in the process of implementing those measures sets the difference between the decisions of the Spanish Revolutionary Six Years Period and the actions undertaken by the political leaders of the French Third Republic. ${ }^{20}$

The third phase, which coincides with the Restoration (1874-1923) and the Dictatorship of General Primo de Rivera (1923-1930), was the most homogeneous one. During the Restoration, of which the Dictatorship represented only the epilogue, the “peaceful turn” political system, agreed upon by the Conservative and Liberal Parties, was established. ${ }^{21}$ Under this regime, the confessional character of the State was reenacted when the 1876 Constitution recognised that “Ia religión católica, apostólica y romana es la del Estado" (“the Catholic, Apostolic and Roman religion was that of the State"). The traditional alliance between "the Throne and the Altar" was, however, not reproduced. The Restoration regime worked to consolidate a point of balance that could satisfy the Church while preventing the growing apart of the political and social groups that had supported the 1868 Revolution. ${ }^{22}$

For the fourth time that century, the Church made a new effort to reorganise its hierarchy and its clergy, and on this occasion, the return to Spain of all the regular orders was, at last, possible. The expansion of the regular clergy did indeed reach its peak during this period. However, the long Restoration years were not without unrest, and the anti-clerical wave of the first decade of the $20^{\text {th }}$ century also affected Spain. The Jesuits were expelled from Portugal; in Mexico, together with the revolution that followed the long government of Porfirio Díaz anti-clericalism flared up and was 
transformed into an anti-religious movement that provoked the "Cristera" Civil War; in France, the Waldeck-Rousseau Law (1902) forced religious associations to be listed in the civil registry and to submit to the intervention of the State; furthermore, it expelled a high number of members of religious orders from the country. ${ }^{23}$ In Spain, anticlericalism grew at the same pace as the Restoration system looked for the support of the Church in order to survive. Spanish anti-clericalism was manifested in the attempts of the Liberal Party to intensify the State's supervision of religious schools, to renegotiate the 1851 Concordat, to secularise marriages and cemeteries and, above all, to adopt measures so as to control the expansion of the religious orders. Their number of members had greatly increased in the last decade due, among other reasons, to the arrival of European brothers (Portuguese and French), and thus a "proletariat of cassocks" was created that needed to be somehow limited. ${ }^{24}$

The climax of the anti-clerical movement was reached in 1909-1910 under the effects of two especially resonant events: the Padlock Law and the Tragic Week. ${ }^{25}$ The Padlock Law (December $23^{\text {rd }}$, 1910) meant to put a limit to the expansion of the religious orders in Spain, the population of which had risen from 15,000 members around 1860 to 60,000 in the first years of the $20^{\text {th }}$ century. ${ }^{26}$ The Law intended to impede the establishment of new religious orders in Spain without governmental permission, a permission which would be automatically denied in case one third or more of the order's population was composed of foreign members. ${ }^{27}$ However, the fearinspiring law was only a compromise solution negotiated by the Conservative and the Liberal Parties. On the one hand, it insisted on closing the door to new orders wishing to settle in Spain because almost all the existing orders were already active in the country. On the other hand, due to a late added clause which stated that the Padlock Law would expire within two years if in the meantime a Law of Associations was not enacted, the 
Law actually amounted to nothing. ${ }^{28}$ The second event was the Tragic Week in Barcelona, a popular revolt that started as a protest against the colonial war in Africa and derived, among other manifestations, into a violent anti-clerical wave that caused, in its excesses, the burning of churches, convents and schools. ${ }^{29}$

The Second Republic and the Civil War (1931-1939) represent the fourth phase. ${ }^{30}$ Two were the central issues that provoked the confrontation between Republican politicians and the Catholic Church: the Constitution and education. The Republican Constitution, in its article 26, stated that religious orders could neither accumulate properties nor develop industrial, commercial or educational activities, being subjected to the general tax legislation. ${ }^{31}$ Those orders that, in addition to the three canonical vows, imposed a special fourth vow of obedience to an authority other than the legitimate one of the Spanish State were abolished; this was the reason for the abolition and expulsion of the Jesuits. Regarding education, the discussion focused on multi-grade schools and on the possibility for religious orders to keep their schools open. ${ }^{32}$ In the end, religious orders were denied that right, but their members were allowed to teach in the surviving Catholic schools.

Regarding the use of the Church's properties, the Second Republic was confronted with a disoriented Catholic hierarchy: each prelate reacted separately due to the lack of consensus on what to do with the assets. ${ }^{33}$ The relationship between the government and the Church was affected by the government's confiscation of a series of documents related to Cardinal Segura (the Cardinal Primate of Spain) in which parish priests were invited to sell the assets and valuable objects of their parishes. This caused the indignation of anti-clerical groups and precipitated the decision of the government to forbid those sales. ${ }^{34}$ The interception of some documents signed by the Bishop of Vitoria did not help either: among them, there was a report that advised to feign the 
selling of ecclesiastical properties to third persons who were not related to the Church and, to any possible extent, to locate all properties in foreign countries. ${ }^{35}$ The content of these documents confirmed and accelerated the government's procedures leading to the publication of the August $20^{\text {th }} 1931$ Decree which suspended the faculty of selling, transferring and levying taxes on personal properties, real estate or real rights of the Church, religious orders, institutes and houses. ${ }^{36}$

\section{Gestation and foundation of La Agrícola Regional, Sociedad Anónima (Larsa).}

\subsection{Mistrust against Spanish liberal governments: Fear and uncertainty.}

Generally speaking, monastic orders represented the most conservative sector within the Church. They had accumulated hostility against liberal politicians. ${ }^{37}$ On the other hand, the isolation in which the monks lived made them prone to feel harassed by external forces that they could neither understand nor control. Isolation was inherent to monastic communities: they ran their own novitiate and seminaries and the monks spent all their lives in an ecclesiastical society totally closed to external influences. ${ }^{38}$

In order to understand why, in 1913, the Benedictine Community of Montserrat decided to constitute a public limited company to which it transferred its properties, we must get acknowledged with the feeling of enclosure and hounding on the part of the Spanish liberal state experienced by the Benedictines ever since the refoundation of the Monastery in $1844 .{ }^{39}$ In Montserrat, the monks' isolation increased after the election in 1885 of Abbot Deàs, a former diocesan parish priest and a practical man obsessed with the lonely and penitential character of the Sanctuary and with a very conservative point of view regarding the essence of monastic life - and of civil life as well. He had been a good, calculating, and respected treasurer before, a good money saver endowed to manage the finances and resources of the 
Community $^{40}$. From Deàs actions we can infer that he and the whole Benedictine Community must have lived tormented by an uncertain 'liberal' threat that had previously materialised several times. With the purpose of eluding it, in 1883 Deàs asked for a first permission from the Holy Siege to sell the Community's jewels and thus "evitar que los revolucionarios o los gobiernos liberales se apoderen de ellas" ("prevent revolutionary men or the liberal government from stealing them" ${ }^{41}$. The defensive strategy designed by Deàs was double-fold: to assure the generational replacement of the Monastery with the entry of new monks, and to safeguard its patrimony. The abbot consolidated the Benedictine foundations in the Philippines and Australia to benefit from the fact that the Spanish juridical order allowed religious congregations to keep the novitiates open as long as the newly ordained monks were posted in communities outside Spain - a legal front to continue enlarging the Order. ${ }^{42}$ In 1890 the feeling of enclosure was so evident that Abbot Deàs obtained permission from the Community and from the Holy Siege to conceal the Community's money and jewels in a safe place only known by him and the treasurer. ${ }^{43}$ In addition, the Community transferred some of its rural estates to certain monks under a lay and private title (sic). The Council Book (1891) points out that Deàs was ordered to appoint his heirs so as to guarantee the transmission of the properties holding his name, and it also refers that the vineyards recently acquired (1892) in El Bruch were registered as belonging to Brother Pelegrín Bosch. ${ }^{44}$

Spain's growing anti-clerical atmosphere in the first decade of the $20^{\text {th }}$ century did indeed affect the Community. Those were years on which anti-clerical policies were approved by the Liberal Party and on which the 1851 Concordat was being renegotiated, while news coming from other European countries were everything but reassuring. Those coming from France were especially alarming after the passing of the 
Waldeck-Rousseau Law (1902), by which several religious orders were expelled from the country and all religious associations were forced to register as such in the civil registry and to submit to the State's intervention. ${ }^{45}$

These events added to the anguish and fear of Abbot Deàs and the Community at Montserrat. Deàs perceived new threats in the government's attitude towards the regular orders that could be translated into confiscations and even into forced uncloistering. New uncertainties accelerated a defensive strategy that went further than the one previously implemented. The Community approved Deàs' proposal to sell and “monetise” (sic) all the Community’s rural estates and, later on, requested from Rome the corresponding permission to transfer those estates, alluding to the imminent danger of their being confiscated. ${ }^{46}$ The Holy Siege quickly responded (December 1906) allowing the sale, given the "crítica situación actual de las corporaciones religiosas en España" (“present critical situation of the religious congregations in Spain”). ${ }^{47}$ Once the permission was granted, those estates that were still owned by the Monastery were registered as personal properties of relevant Benedictine monks: the estate of "Manso Estruch" (138 hectares, in the villages of Esparraguera and Collbató) was registered under the name of Antonio Marcet i Poal (the future ruling and, later on, titular abbot), while the estate of "Castell del Mas" (13 hectares) and two other neighbouring land plots that amounted to 17 hectares (all of them in the village of Esparraguera) were registered under the name of the abbot, Josep Deàs. ${ }^{48}$

However, the peak of the anti-clerical movement in Spain was reached during the Tragic Week in nearby Barcelona, and with the passing of the Padlock Law. ${ }^{49}$ The reaction of Abbot Deàs was almost immediate. In 1911 Deàs asked Luis Vives, an attorney he trusted, to undertake a juridical study of the Mountain of Montserrat, especially of the buildings built on it, and to determine the way to guarantee the 
ownership of the Community’s entire patrimony. Deàs still worried about the estates since they could be affected by future anti-clerical decrees promulgated by the government in office. The attorney's final report was devastating. ${ }^{50}$ The Mountain of Montserrat was totally owned by the Episcopal Diocese of Barcelona and the buildings built on it were precariously owned by the Community. If the Diocese demanded it, the Community could be disowned since "según las reglas jurídicas actualmente en vigor

\section{(...) todo lo edificado en suelo ajeno cede a favor del propietario de éste" (“according} to the legal rules presently valid (...) all buildings raised on foreign ground belong to the ground's proprietor"). In addition, Vives called the abbot's attention to the fact that the expensive system used to maintain the properties under the name of private people -when these people died, 20 percent of the property's value had to be used to face the payment of real rights- did not eliminate the lack of security in the face of the government's future behaviour. It was worth establishing a new, safer and less expensive mechanism. The attorney's suggestion was clear: the best solution was to create a public limited company, all the better if outside Spain, in a country like England or Germany. The capital of this public limited company would be divided into bearer-shares, so that "straw men” - actually Benedictine monks in the chosen country who would keep their identities secret - managed the company according to the country's laws. Bearer-shares would allow the Community to retain possession of its properties. However, if need be of having another person own the shares, these would only need to be transferred, since the Commercial Code acknowledged the holder's title of a bearer-share only while the opposite could not be proved. The public limited company thus constituted would acquire the Community's properties and would then exploit them on its own, having as well the possibility of renting them to the Community in exchange for the corresponding fee. Concerning the problem with the 
buildings on the Mountain of Montserrat, Vives recommended that the public limited company bought them.

\subsection{The foundation of La Agrícola Regional, S.A. (Larsa).}

In 1912, due to Deàs’ old age, Antonio M. Marcet i Poal was elected ruling abbot of Montserrat and assumed all the executive tasks of his position, although the ecclesiastical dignity associated to it still remained in the hands of Abbot Deàs. ${ }^{51}$ With Marcet in command, the Community of Montserrat progressed along the way designed by Deàs. Just a few months after his designation, Marcet followed the master plan designed by Vives and created a public limited company with bearer-shares.

The report of attorney Vives, favourable to the creation of this public limited company to conceal the Benedictines' properties, reflects the ideas of the Catalonian business current that promoted the legal transformation of companies. In the 1910s, a process started in Catalonia that led many companies to abandon their traditional legal figures (collective regular companies and partnerships) and adopt that of the public limited company. ${ }^{52}$ The choice of the public limited company rendered the Benedictines similar advantages to those experienced by the companies in their economic environment. This figure was probably not an unknown and strange tool for an abbot like Marcet, who belonged to a family of industrialists. ${ }^{53}$ In addition to being a principle of this business current, the public limited company appeared before the monks as an instrument powerful enough to conceal their patrimony and to cause sufficient juridical trouble to the State in case it intended to undertake confiscation. In this line, the Jesuits had been using public limited companies ever since the end of the 19th century. The historical Jesuit regions of Castile and Aragon opted for this strategy during the anticlerical period of 1906-1914, but the Jesuits' first public limited company was actually created in 1883 (La Enseñanza Católica S.A.). If the Society of Jesus has the privilege 
of having introduced this innovatory strategy, we can nevertheless point to the dreadful choice of the companies' names (La Educación, S.A., La Instrucción, S.A., La Instrucción Católica, S.A., La Enseñanza Católica, S.A.) that evidenced their origin and owners, and to their inoperative management. ${ }^{54}$

In the autumn of 1913 both incentives converged in the constitution of Larsa, the Benedictine public limited company. Nevertheless, its creation was not the result of a current of ecclesiastical modernisation towards less archaic ways of acting, behaving and thinking. Neither was it indirectly provoked by the pressure of the State on the Church - an institution accused of being archaic and retrograde in what concerns economic growth and social progress. We feel more inclined to argue that public limited companies belonging to regular orders - and the Benedictine company was no exception - were the consequence of the orders' fear of losing the patrimony they had been able to rebuild with such great efforts during the last decades. In the case of Montserrat, the difference is that the public limited company evolved to become an efficient tool for the management of the order's properties, something that the Jesuits did not achieve with their companies, which could not even fulfil the objective of avoiding confiscation. ${ }^{55}$

La Agrícola Regional S.A. (Larsa) was founded on October $31^{\text {st }} 1913$ and its social capital amounted to 300,000 pesetas (see Table 1) represented by 300 bearershares. Its purpose was the purchase and sale of rural and urban estates, the exploitation of agrarian products and other legitimate businesses the associates might agree upon. ${ }^{56}$ The founding share-holders were carefully selected by the ruling abbot Marcet, as it is reflected on a letter dated July 1913 and written by notary Joaquín Dalmau to Marcet, willing to find out whether "ya tiene localizadas a las personas que [la] funden como constituyentes" ("he had located the people to found it as constituents"). ${ }^{57}$ The 
persons selected were: president Francisco Cabot i Rovira (75 shares, a trustworthy man, as proved in previous assignments), vice-president Juan Marcet i Palet (80 shares, the ruling abbot's cousin), secretary Francisco Mundó i Fló (30 shares, the ruling abbot's brother-in-law), and members Juan Colomé i Trayté (50 shares, a trustworthy attorney who had faithfully served Abbot Deàs in 1906-1907), Josep Marcet i Poal (35 shares, the ruling abbot's brother) and Francisco Suñol i Baulenas (30 shares, brother to a Benedictine monk). ${ }^{58}$

With the front company thus constituted, the following step was to transfer the rural properties to the company through the juridical artifice of a simulated sale. ${ }^{59}$ The account of the purchase and sale procedure, reproduced in the Minute Book of $L a$ Agrícola Regional, is written as a novelistic plot to hold the simulation, hoping to avoid a governmental intervention that could prove the feigning and confiscate the public limited company. The records explain how Juan Colomé read in the papers that abbots Deàs and Marcet were to visit Barcelona, and how he informed the president of the company; how the president met the abbots in order to confirm the rumour that said they meant to sell the Community's estates and how he presented a first offer for those lands. During the meeting, the abbots corroborated Francisco Cabot, the commercial agent presently managing their economic activities, on their wish to sell the estates. The negotiation to establish the final price of the estates is also recounted in detail. A paragraph of a letter from Deàs to Larsa expresses the monks' interest in taking precautions against possible future menaces:

“[los abades] pues prevén el día en que la propiedad de los religiosos en España, sea en su nombre individual o colectivo será seriamente amenazada y tanto es así que sabe que el Rmo. P. Coadjutor desde que tomó posesión de su cargo en enero último no ha dejado este negocio un solo punto y poco antes de salir de Montserrat el pasado domingo, se recibió en dicho Monasterio una carta dirigida al P. Simó, Subprior, fechada en Roma en 7 u 8 del corriente en que entre otras cosas le manifestaba el Rvdo. P. Marcet que sería conveniente que apenas vuelto de su viaje pudiera, él y todos los demás monjes propietarios vender sus fincas y posesiones” 60 
("[the abbots] thus foresee the day on which the property of religious orders in Spain, be it under individual or collective name, will be seriously threatened and it is so that the Reverend Ruling Father has not mistreated the issue ever since he was appointed in January, and right before leaving Montserrat last Sunday a letter was received in this Monastery addressed to Father Simó, Subprior, dated in Rome on April $7^{\text {th }}$ or $8^{\text {th }}$, on which, among other things, Reverend Father Marcet manifested that just after his return it would be appropriate that he and the rest of the monks proprietors sold their estates and possessions.”)

After these comings and goings, on December 1913, Larsa's Share-holders General Assembly made a firm offer of 127,100 pesetas for all the estates, 185 hectares altogether. ${ }^{61}$ The breakdown of the estates transferred was the following:

1. “Manso Estruch”: 62,300 pesetas (32,500 pesetas for the land in Esparraguera and 29,800 for the land in Collbató).

2. Estate in the Mountain of Montserrat: 2,800 pesetas.

3. “Manso Castell”: 45,500 pesetas.

4. $\quad$ Neighbouring rural estate: 4,500 pesetas.

5. $\quad$ Neighbouring rural estate: 11,000 pesetas.

6. Neighbouring rural estate: 500 pesetas.

7. Vineyard in El Bruch: 500 pesetas.

The land purchase and sale was closed in February 1914 and in May the estates were rented to the Benedictine Community, thus concluding the plan designed by the attorney Vives three years earlier. ${ }^{62}$ The renting conditions were favourable to the Benedictines:

“ $1^{a}$. No arrendarlas a la Rda. Comunidad de Montserrat por mayor tiempo de cinco años, si bien dicho arrendamiento puede ser confirmado una ó más veces por cinco años más previo mutuo consentimiento de ambas partes.

$2^{a}$. La cantidad mínima mensual queda fijada en 420 ptas., pagaderas por trimestres anticipados.

$3^{a}$ las contribuciones directas y defensa agrícola etc. $Y$ otras indirectas sobre las mimas fincas, irán a cargo y nombre de la sociedad.

$4^{a}$ las contribuciones industriales que tal vez afecten a industrias que se ejerzan en las mismas, a cargo de los arrendatarios.

$5^{\circ}$. Los gastos para abonos químicos, máquina agrícolas, análisis de tierras, trabajos experimentación y repoblación de cultivos con especies nuevas, de instrumentos y aperos nuevos, irán a cargo de la sociedad.

$6^{0}$. Los gastos para reparación de máquinas, renovación de aperos e instrumentos, irán a cargo de los arrendatarios quienes cada año presentarán un inventario de los instrumentos nuevamente adquiridos y de los que hayan resultado inútiles para el servicio.

$7^{\circ}$. Los consumos y otros impuestos municipales serán objeto de mutua discusión al establecer el arrendamiento." ${ }^{63}$ 
"First. The estates will not be rented to the Reverend Community of Montserrat for a period longer than 5 years, although this renting can be confirmed one or more times for five more years if the two parts mutually consent.

Second. The minimal monthly amount is fixed in 420 pesetas, to be paid in advance every three months.

Third. Direct contributions, such as the agrarian defence, and indirect contributions to the estates will be the company's responsibility as title-holder.

Fourth. Industrial contributions that may affect the industries developed in those estates will be the tenants' responsibility.

Fifth. The expenses on chemical fertilisers, agrarian machines, soil analyses, and experimentation and repopulation tasks developed with new species and tools in the estates will be assumed by the company.

Sixth. The expenses in repairing machinery and renewing tools will be assumed by the tenants who will annually present a list of the tools newly acquired and of those that have turned useless for their service.

Seventh. Consumptions and other municipal taxes will be discussed when the renting is established."

Larsa received 10,000 pesetas per year from renting the estates. The company's managers immediately started an improvement program which included the introduction of electric power in the estates, the intensification in the use of fertilisers, the renewal of the machinery and the increment of the patrimony. All the lands purchased by Larsa from the beginning of the 1930s were rented to the Community. In this land purchase process, we can underline the acquisition in 1920 of a 45 hectares estate in the Mountain - still registered under Deàs' name - for 1,000 pesetas, and the purchase of a small land plot in Collbató (1 hectare) for 500 pesetas, allowing for the rounding up of the property of "Manso Estruch”. In 1924, “Can Martorell” (27 hectares) was bought with a 25,000 pesetas loan - redeemable in five years - granted to Larsa by the Benedictine Community. In 1931, Larsa bought a small estate, neighbour to "Can Estruch”, for 600 pesetas. Trying to improve the patrimonial situation of the estates, Larsa also developed a policy that led to the purchase of the rabassas, ground rents and emphyteusis that taxed these lands with 128,025 pesetas (January 1919). ${ }^{64}$

\section{Larsa's transformation: From an agrarian company to a services company.}

In April 1931, the Second Republic was proclaimed in Spain and, together with the change of regime, the religious communities' forecast for the future became more pessimistic. By then, the Jesuits had already taken further precautions. The Provincial 
Father in Leon had stated, already six months before the establishment of the Republic, that the assets had to be concealed and the properties simulated. And the head of the religious house in Madrid was, already at the end of 1930, looking for possible ways for his Jesuits to flee. Right after the proclamation of the new regime on April $14^{\text {th }}$, a meeting of the Jesuit provincial fathers was held (April $27^{\text {th }}$ ) meant to decide on how to secure the buildings and act in relation to the public limited companies that had until then camouflaged their schools. They decided to ask Rome for permission to sell, mortgage or pignorate their properties (the permission was granted on April $30^{\text {th }}$ ) and to improve the model of public limited companies, because the existing ones were poorly constituted and managed, and it would be very easy to find out who were their actual owners - the companies' names clearly indicated that they belonged to a religious institution. ${ }^{65}$

Although they had already transferred their estates, the Benedictines were again fearful at the thought of what could happen with the Mountain of Montserrat, where the Sanctuary, the Monastery and the annexes that housed their businesses were located and with the businesses themselves. The Community was aware that the Mountain belonged to the Episcopal Diocese of Barcelona and that the buildings were in a situation of juridical indeterminacy. The Community could not register their names in the property registry since they were built on the land of the Bishop of Barcelona, who would be granted the property of the buildings the moment he claimed it. But if the Mountain were confiscated from the Bishop of Barcelona, the new owner of the land would immediately become the legal proprietor of the buildings, with the right to recover them any time. The industrial and commercial activities that the Benedictines operated in the annexes of the Sanctuary were a different issue. They 
belonged to the Community although the buildings that housed them were in a situation of legal indeterminacy.

Abbot Marcet proved to be swift and clever on his decision concerning the annexes of the Monastery and the businesses there developed. On May $1^{\text {st }} 1931$, a few days after the proclamation of the Republic and spurred by the burning of churches and convents in Madrid, Malaga and Seville, the Benedictines made a double decision. First, to buy land in Andorra under the premise of having a place where "refugiar-se la Comunitat en cas de venir l'espulsió de les ordes religioses" (“the Community could seek refuge if the religious orders were finally expelled”) and, second, to transfer all the assets and services owned by the Community to La Agrícola Regional in order to build funds for the new land purchases. They transferred the grocery store, the liquor factory, the rooms, the hotel and restaurant, the garage and the restaurants in the Mountain, together with the religious house in Barcelona. The name of the holders of the Community's current accounts were also changed so that now, instead of the juridical figure of the Monastery, the abbot and the treasurer held them individually under lay and private titles. ${ }^{66}$

At the beginning of July 1931 the Benedictines initiated the actions to make effective the renting of their services to Larsa. The operation meant that the company had to grow in order to finance the expansion, and it could do it either through indebtedness or by asking its share-holders to confront a share offer. Larsa was managed under the parameters of guaranteeing its longevity and keeping its control in the hands of the monks, and in order to achieve those objectives the best possibility was to increase its own resources through a 350,000 pesetas capital increase, which raised the company's capital to 500,000 pesetas (Table 1). The share-holders assumed this capital increase to avoid the participation of strangers in the operation. ${ }^{67}$ The transfer 
was thus quickly effected and signed on July $30^{\text {th }}$ 1931. Just in time, because the Republican government soon passed a decree that suspended the faculty of the Church, religious orders, institutes and houses to sell, transfer and levy taxes on personal estate, real estate or real rights (August $20^{\text {th }}$ 1931). Later on, the Republican Constitution established that religious orders could neither accumulate assets nor develop industrial, commercial or educational activities, being subjected to the general tax legislation. ${ }^{68}$ Larsa's Shareholders Extraordinary General Assembly approved to rent the establishments directly run by the Community and those the Community had previously rented to third parties. The purchase of the furniture and goods used in those establishments was also decided upon. The contract was signed on August $18^{\text {th }}$ and it settled the rent on 200,000 pesetas per year to be paid by Larsa to the Community for renting the businesses pertaining to the monks. The breakdown was as follows:

Hospices (San José, San Alfonso, Venerable and Nuestra

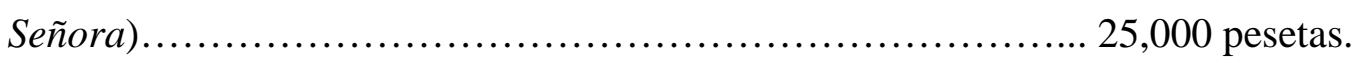

Hotel and Restaurant at the Monastery...................... 75,000 pesetas.

Garage.............................................. 15,000 pesetas.

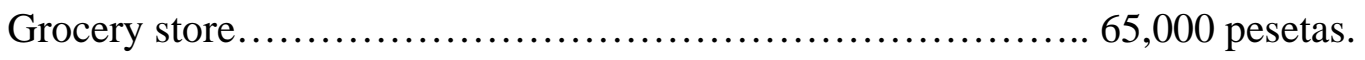

Barber shop.............................................. 50 pesetas.

Public toilets........................................... 1,900 pesetas.

Kiosks at the fountain square............................. 3,000 pesetas.

Restaurant Santa Cecilia.................................. 4,025 pesetas.

Restaurant San Juan.................................... 4,025 pesetas.

Restaurant San Jerónimo................................... 7,000 pesetas.

The purchase of materials and goods effected by Larsa included the furniture of the different stores (counters, shelves, showcases, etc.), decorative elements (lamps, etc.), the motor engines in all installations, the trousseau of the different hotels (beds, 
cradles, towels, linen, pillows, etc.) and restaurants (including kitchenware and electrical appliances), cold and hot water installations, the furniture of the hotels and restaurants (tables, wardrobes, counters, armchairs, sofas, chairs, carpets, etc.) and “cuantos muebles ropas, utensilios, máquinas, enseres, accesorios, útiles y demás bienes muebles” (“all furniture, clothes, tools, machinery, accessories, belongings and personal estate") - all of it for 76,250 pesetas. ${ }^{69}$ In other words, the monks monetised all the personal estate from the different businesses since having liquidity available was enormously advantageous in case they were finally expelled from the country.

Within four months, Abbot Marcet had implemented new strategic lines. He had created a new front company named Cultural Andorrana, formed by Father Pemtebre, native of Andorra, and other Fathers and laymen. This company was responsible for purchasing new land in Andorra. The services developed in the annex buildings of the Monastery had been rented and all the personal estate had been sold to La Agrícola Regional. ${ }^{70}$

Parallel to this, Larsa changed the way on which the different businesses were organised. In taking control of its new activities, Larsa discovered that the system used by the Benedictines was paternalistic, based in the trust generated by the tenants' dependence on the monks, and excessively tolerant. The Administration Board concluded that the inherited model could not be maintained if a better management was to be established with the aim of generating more profit. Larsa started a process that aimed to create "un nuevo régimen de organización y control de todos los servicios en general” (“a new system to organise and manage all the services”), and very soon "a regime of control" was implemented that did not exist before. The mechanism applied was the substitution of the monks in charge of the different 
activities by personnel hired ex professo by the company to accomplish each task. However, the monks stayed some time in their positions so as to transmit their knowhow to the new personnel. To lead this process, the Administration Board decided to hire an "administrador o gerente" (administrator or manager). ${ }^{71}$

\section{Larsa's business strategies.}

Before analysing the strategy implemented by Larsa's managers it is important that we define the company's characteristics and objectives. Both characteristics and objectives determine the strategy applied on any given moment. Larsa's characteristics included its being a small-size company (Table 1), its “organic” development (through the reinvestment of profit), and its infrequent resort to the financial and capital markets (it was circumscribed to short-term commercial financing). ${ }^{72}$ Larsa's objectives contemplated the assurance of the company's longevity as the only mechanism able to guarantee the maintenance of the Order's patrimony and therefore the survival of the Monastery and the Community. ${ }^{73}$ The second objective was to keep the control of the company in the hands of the Community through several "straw men". Trustable persons, external to the Community, had to be appointed to occupy the different positions at the Administration Board, since the monks could not be members of it: technically speaking, they were not share-holders, and, in addition, they absolutely needed to preserve Larsa's screen-like character, which would have been revealed through their presence in this company's body. ${ }^{74}$

Two were as well the strategies implemented by Larsa. The first one, developed between 1914 and 1934, can be called conservative in the first and strictest sense of the word: to help preserve the business and to secure the Community's control over it. In this line, Larsa preferred to enjoy greater solidity by avoiding delicate financial situations. The strategy sacrificed profitability - lesser benefits but a solid company 
basis - and growth - smaller size, better control. In those years, Larsa behaved in a similar way to other companies in Catalonia ${ }^{75}$. For instance, cotton textile companies, most of them family-owned and run, had similar objectives, characteristics and strategies, and they were all financially solid, their own resources representing more than 60 percent of their capital ${ }^{76}$.

Larsa's new strategy after 1934 involved a change of objectives, which now were focused in endowing the Community with the greatest liquidity available, even if it meant sacrificing the financial stability of the company. ${ }^{77}$ After that date, Larsa's behaviour differed from that of other companies in its environment, which were not affected by the political instability of the Republic and were able to maintain their financial structure without effecting alterations meant to increase liquidity. The question, left unanswered in the introduction, regarding the possible differences between the companies directed by members of religious orders and those managed by laymen is now responded. Larsa, which was Benedictine-owned, decided to transform its conservative strategy into a new one designed to generate liquidity and it did it with the change of political regime and, especially, after the October 1934 Revolution, spurred by the monks' fear of losing their properties and of being expelled from Spain. ${ }^{78}$

The available accounting data allow us to approach the economic-financial activity of Larsa, which was based on two different mechanisms: self-financing and the allocation of reserves. These mechanisms allowed the Benedictine firm to achieve great solidity, since we cannot even speak of indebtedness ratios in the case of Larsa: it had almost no accounts payable, and no long-term debts at all (Table 2). The company grew upon its own resources. Its own capital was hegemonic ever since the foundation, so that Larsa was over-capitalised from the beginning and it was forced to start a reduction process of its social capital in 1917 (Table 1) because it owned 150,000 pesetas that had 
not been invested and were thus unproductive. In 1931, the company had to face an important capital expansion when it rented the Community's buildings and services and bought the personal estate in them. ${ }^{79}$ Regarding the expansion of 1934 , the scarce information available on it indicates that it was undertaken in order to meet the exploitation of the Cable Car to Montserrat ${ }^{80}$. During the period analysed, there were only two exceptions on which the company resorted to external financing: the first one, when it increased its rural patrimony with the purchase of "Can Martorell" through an interest-free loan, redeemable in five years, granted by the Benedictine Community. On the second occasion, in 1929, the Community lent Larsa 20,000 pesetas to finance different improvement works undertaken in the estates (supra), to cover the high expenses on fertilisers and to support the introduction of bovine cattle and pigs in its lands. In both occasions, Larsa behaved exactly like the companies in its geographical surroundings, which became indebted with the members of the family that owned the firm to avoid resorting to external lenders. This type of action was very frequent, for example, among Catalonian cotton-producing families that granted loans in favour of their companies. ${ }^{81}$ The other basic column sustaining the financial solidity of the company was the allocation of reserves that grew together with the benefits and were supported by the lack of dividend distribution. ${ }^{82}$ The decision of creating a contingency fund account to hold each year's profit and retained earnings was adopted by the General Shareholders Meeting in February 1919, being implemented in 1920. The amount initially deposited in that account was 5,372 pesetas. The General Shareholders Meeting of 1926 insisted on increasing the contingency fund to $\mathbf{1 5 , 0 0 0}$ pesetas by means of not distributing the dividends, and on the 1929 Meeting the President declared that it was impossible to distribute the dividends when the priority was to refund the credit granted by the Community 
and safeguard reserves. ${ }^{83}$ The accumulation of the contingency fund was only temporarily interrupted in 1930 when the reserves were used to redeem the 20,000 pesetas loan of the previous year. It happened again in 1934-1935 when, under the pressure of the special institutional frame of this period and following the advice of the Administration Board, two dividend distributions were implemented.

In the previous paragraphs we described the geographical-entrepreneurial setting in which Larsa can be framed, but this setting does not allow us to compare the evolution and profit level of the different companies. Catalonian and Spanish companies experienced a phase of singular prosperity during the years of the First World War and the immediate post-war period. In those years earnings were extraordinary and the companies' high profitability hinders any possible comparison with Larsa. $^{84}$

In the evolution of Larsa's profits two periods can be distinguished: before and after the proclamation of the Second Republic. Before 1931, the company was just the owner of some rural estates, and business objectives were not focused on maximizing profits but on increasing, maintaining and improving the properties. Profitability, in relation to the company's own resources, was minimal until 1924. From that year onwards, and after investments were made in order to increase and improve the patrimony, profitability grew during a six-year period reaching 4 percent in 1930 (Graph 1). ${ }^{85}$ This behaviour was feasible if we consider that Larsa had been created neither to generate high profitability nor to be a reference company in managing rural patrimonies. Its objective had always been to safeguard the Community's properties from undetermined future governmental confiscations. With the establishment of the Republic, the business model and its administration were modified. Larsa became a company focused in the management of commercial services, and it improved its 
functioning and increased its economic activity and profits, thus allowing for an increment of the reserves from 20,000 pesetas in 1930 to 117,000 pesetas in 1933.

The information drawn from the documents corresponding to the years immediately before the Civil War (1934-1936) is fragmentary and only allows establishing working hypothesis. After the 1934 October Revolution and due to the growing uncertainty regarding the political future of the Second Republic, the Administration Board changed the business strategy, which now concentrated in assuring financial liquidity. The hypothesis is based on the fact that the profits in 1934 and 1935 were mainly the result of a decrease in the surplus accumulated in previous years, not the outcome of business dynamics. In fact, reserves dropped from 117,000 pesetas in 1933 to 37,000 pesetas in 1935 (Table 1). Second, the disposable capital of the company rose from 5,500 pesetas in 1933 to 100,000 in 1935 . Finally, Larsa twice effected a dividend distribution (71,500 pesetas) so that the liquidity generated was partly transferred to the real owners, the monks.

The hypothesis that sustains this behaviour points to the monks' fear of being uncloistered or even expelled from Spain. Larsa's liquidity served them to have money available to face an undetermined future. The dividends perceived would help the Community to purchase land in Andorra in case they were finally expelled from the country, and to increase the Community's investment in safe assets, many of which were located in foreign countries, easily transported and negotiated if need be.

This hypothesis leads us to one last issue that must be analysed: the Community's investment policy. The Benedictines had for a long time invested their incomes in liquid assets that could be conveyed and hid in case the government decided to act against them. Therefore, the bulk of the Benedictine properties was constituted by movable assets, carried or sold without difficulty. The Monastery's directive board 
rapidly invested the liquidity surplus generated. Thus, in 1892, the treasurer of the Monastery was ordered to decide where to invest the surplus generated, preferably in safe assets such as State paper and railways. ${ }^{86}$ The documents analysed reflect, for example, the agreements reached in 1913 and 1914 according to which investments were made in Riegos del Ebro (25,000 pesetas), public debt at 4 percent (25,000 pesetas), the "Turkish loan” (5,000 pesetas) and bonds of the railway to San Juan de las Abadesas (5,000 pesetas). ${ }^{87}$ The portfolio's nominal value in 1933 amounted to 458,775 pesetas, 39,705 Chilean dollars and 18,300 Italian lire. ${ }^{\mathbf{8 8}}$ The structure of the portfolio showed a balance between fix and variable income. Of the part valued in pesetas, 36.35 percent (166,800 pesetas) was invested in public debt while the remaining 63.65 percent (291,975 pesetas) was destined to purchase company bonds. The Chilean currency was almost totally invested in the variable income of companies settled in that country, thus balancing the investment in Italian public debt.

\section{Conclusions.}

First, we would like to highlight the fact that the abbots' political-strategic vision, especially that of Abbot Marcet, was the cornerstone of the success in Montserrat. Through the text, we have underlined the swiftness and agility showed by the Benedictine Community at Montserrat in adapting the holdership and management of its estates and services to the changing Spanish political context. In all occasions, the Community acted almost at the same speed as the actual events happened. Abbot Deàs' movements were rapid at the beginning of the 20th century, when he asked Rome for permission to transfer the Community's properties to individual monks. The decisions made by Abbot Marcet were as well extremely agile when, in the last 1910s, he set off the creation of Larsa. We must again highlight how, less than two months after the proclamation of the Second Republic, the Community transferred to Larsa the 
management of the services annexed to the Monastery and sold the company all the personal estate that was susceptible of being confiscated.

These actions, which could be qualified as defensive, led to the actual externalisation of the Community's activities that were thus assumed by the affiliate company. Larsa's Administration Board undertook the process of improving the management of the services, transforming the inherited unprofitable paternalistic system into a directorship that reinforced control of the business units. Profit therefore increased as well, helping the monks to augment their dividends when they needed greater liquidity during the years of the Second Republic.

Regarding Larsa's objectives, characteristics and strategies, they present similarities with other companies established in Catalonia. Larsa was characterised by a strong capitalisation, minimum resort to external capital and profit reinvestment. Generally speaking, it was a conservative strategy meant to guarantee the company's survival and to keep control in the hands of the Benedictine monks. The strategy only changed during the years of the Second Republic, when Larsa distributed its dividends and the immediate interest of the actual proprietors prevailed: to increase liquidity, leaving on the background the financial solidity of a company that could be confiscated and collectivised any moment. In those years, Larsa's behaviour differed from that of the companies in its environment, which did not seem to be affected by political instability. And we must as well consider that Larsa resembled a family firm, a majority in the Catalonian businesses sector, in what concerns its objectives, characteristics and strategies.

Finally, the objectives that the monks set for Larsa were totally fulfilled. The company achieved that of longevity - it is almost 100 years old by now - and at the same time guaranteed the Benedictines' control over it, something that the Jesuits could 
not accomplish. The reason for this double success lies in that a clever legal division between the Community, the company and the properties was established that secured the control of the patrimony even during the most critical years of the Second Republic. In addition, this division helped improve the economic results of the properties and businesses managed by Larsa back then and still nowadays.

\section{REFERENCES.}

Albareda i Ramoneda, Anselm M.: Història de Montserrat. Montserrat: Publicacions de l’Abadia de Montserrat, 1988.

Andrés-Gallego, José. La política religiosa en España, 1889-1913. Madrid: Editora Nacional, 1975.

Andrés-Gallego, José. La Iglesia en la España contemporánea, Madrid: Ediciones Encuentro, 2 vol., 1999.

Astrachan, Melissa Carey; Shanker, Joseph H. "Family businesses' contribution to the U.S. economy; A closer look”, Family Business Review, vol. 9 (n 2, 2004): 107-123.

Bernecker, Walther L. España entre la tradición y la modernidad: política, economía, sociedad: (siglos XIX y XX). Madrid: Siglo XXI, 1999.

Branden, Charles. S. "Church and State in Spain”, Church History, Vol. 3, No 3 (Sep., 1934): 207-221.

Cabana, Francesc. La burguesía catalana. Una aproximación histórica. Barcelona: Edicions Proa, 1996.

Cabana, Francesc. Fàbriques i empresaris. Els protagonistes de la revolució industrial a Catalunya. Barcelona: Diputació de Barcelona, 2001.

Cabrera, Mercedes. "Proclamación de la República, constitución y reformas” in Menéndez Pidal, Ramón. Historia de España, vol. XL. Madrid: Espasa Calpe, 2004: 357. 
Callahan, William J. Church, Politics and Society in Spain, 1750-1874. Cambridge: Harvard University Press, 1984.

Callahan, William J. The Catholic Church in Spain, 1875-1998. Washington, D.C: The Catholic University of America Press, 2000.

Callahan, William J. “Los privilegios de la Iglesia bajo la Restauración, 1875-1923” in Boyd, Carolyn P. Religión y política en la España contemporánea. Madrid: Centro de Estudios Políticos y constitucionales, 2007: 17-32.

Cárcel Ortí, Vicente. "El liberalismo en el poder (1933-1968) in García-Villoslada, Ricardo (dir.) Historia de la Iglesia en España, Madrid: La Editorial Católica, 1979: 115-226.

Cárcel Ortí, Vicente. “La II República y la Guerra Civil (1931-1939)” in GarcíaVilloslada, Ricardo (dir.) Historia de la Iglesia en España, Madrid: La Editorial Católica, 1979: 331-394.

Cárcel Ortí, Vicente. Historia de la Iglesia en la España contemporánea. Madrid: Ediciones palabra, 2002.

Cardoso, Ciro F.S.; Pérez Brignoli, Héctor. Historia Económica de América Latina. Vol. 2.Economía de exportación y desarrollo capitalista. Barcelona: Crítica, 1979.

Carlock, Rander S.; Ward, John L. La Planificación Estratégica de la Familia empresaria. Barcelona: Ediciones Deusto, 2003.

Carmona, Salvador; Ezzamel, Mahmoud. “Accounting and religion: a historical perspective”, Accounting History, vol. 11 (n 2, 2006): 117-127.

Carr, Raymond. España 1808-1975. Barcelona: Ariel, 1996.

Casson, Mark. “The Economics of the Family Firm”, Scandinavian Economic History Review, vol. 47, (n 1, 1999):10-23. 
Channon, Derek F. The Strategy and structure of British Enterprise, London: Macmillan, 1971.

Colli, Andrea, Rose, Mary B. "Families and firms: The Culture and Evolution of Family firms in Britain and Italy in the Nineteenth and Twentieth Centuries”. Scandinavian Economic History Review, vol. XLVII, (nº 1, 1999): 24-47.

Colli, Andrea; Fernandez, Paloma; Rose, Mary B. "National Determinants of Family Firm Development? Family Firms in Britain, Spain, and Italy in the Nineteenth and Twentieth Centuries”, Enterprise \& Society 4, 1 (2003): 28-64.

Colli, Andrea. The History of Family Business 1850-2000. Cambridge: Cambridge U.P., 2003.

Cuenca Toribio, José M. La Iglesia española ante la revolución liberal, Madrid: Rialp, 1971.

Cuenca Toribio, José M. Aproximación a la historia de la Iglesia contemporánea, Madrid: Rialp, 1978.

Cuenca Toribio, José M. Iglesia y burguesía en la España liberal. Madrid: Pegaso, 1979.

Cuenca Toribio, José M. Relaciones Iglesia-Estado en la España contemporánea. Madrid: Alhambra, 1989.

Cuenca Toribio, José M. “La historiografía eclesiástica española contemporánea: balance provisional a finales de siglo (1976-2000)” in Andrés-Gallego, José. La historia de la Iglesia en España y el Mundo Hispano. Madrid: UCAM, 2001: 263-316.

De la Cueva Merino, Julio. “Anticlericalismo e identidad anticlerical en España: del movimiento a la política (1910-1931)” in Boyd, Carolyn P. Religión y política en la España contemporánea. Madrid: Centro de Estudios Políticos y constitucionales, 2007: 165-186. 
De Maeyer, Jan; Leplae, Sofie; Schmiedl, Joachim. Religious Institutes in Western Europe in the $19^{\text {th }}$ and $20^{\text {th }}$ Centuries. Leuven: Leuven University Press, 2004.

Díaz Hernández, Onésimo. “La “Ley del Candado” en Álava”, Sancho el Sabio. Revista de cultura e investigación vasca, 11, 1999: 143-160.

Domínguez Ortiz, Antonio. "Patrimonio y rentas de la Iglesia” in Enciclopedia de Historia de España, Vol. 3., dir. Miguel Artola. Madrid: Alianza Editorial, D.L. 1988: 75-158.

Dorel-Ferré, Gracia. Les colònies industrials a Catalunya: el cas de la Colònia Sedó, Montserrat: Abadía de Montserrat, 1992.

Fernández Pérez, Paloma. "La empresa familiar y el «síndrome de Buddenbrook» en la España contemporánea: el caso Rivère (1860-1979)” in Doctor $J$ Nadal: la industrialización y el desarrollo económico de España, Barcelona: Universitat de Barcelona, 1999:

Fernández Roca, F. Javier. "The adaptative strategies of Spanish cotton industry companies, 1939-1970”. Business History, vol. 49, (nº 1, 2007): 75-97.

Frías Fernández, Juan C. “Percepciones, imágenes y explicaciones de la recuperación económica de la Iglesia: los anticlericales entre 1876-1899” in La parra, Emilio; Pradells, Jesús. Iglesia, sociedad y estado en España, Francia e Italia (ss. XVIII al XX). Alicante: Instituto de Cultura Juan Gil Albert, 1992: 173-184.

Frías García, M. Carmen. Iglesia y Constitución. La jerarquía católica ante la II República. Madrid: Centro de Estudios Políticos y Constitucionales, 2000.

García de Cortázar, Fernando. “La Iglesia en la crisis del Estado Español, 1898-1923” in Tuñon de Lara, Manuel et al. VIII Coloquio de Pau: la crisis del estado Español, 1898-1936. Madrid: Cuadernos para el Diálogo, 1978: 343-377. 
Granovetter, Mark; Swedberg, Richard. The Sociology of Economic Life. Boulder (Colorado): Westview Press. 1992

Granovetter, Mark. "Economic institutions as social constructions: a frame work for analysis”. Acta Sociologica, (n 35, 1992): 3-11.

Granovetter, Mark. "Coase revisited: business groups in the modern economy". Industrial and Corporate Change, vol. 4, ( $\mathrm{n}^{\circ}$ 1: 1995): 93-130.

Haber, Stephen.; Razo, Armando. "Political Instability and Economic Perfomance”, Worlds Politics, vol. 51, (n 1, 1998): 99-143.

Handler, Wendy C. "Methodological Issues and Considerations in Studying family Business”. Family Business Review, Vol. II, (nº 3, 1989): 257-276.

Herr, Richard. Ensayo histórico de la España contemporánea. Madrid: Pegaso, 1977.

Jacobs, Kerry; Walker Stephen P. "Accounting and accountability in the Iona Community”, Accounting, Auditing \& Accountability Journal, vol. 17 (nº 3, 2004): $361-381$

Jones, Geoffrey; Rose Mary B. (eds.) “Special Issue on Family Capitalism”, Business History, vol. 35 (n 4, 1993).

Kreander, Niklas; McPhail, Ken; Molyneaux, David. “God's fund managers. A critical study of stock market investment practices of the church of England and UK Methodist”, Accounting, Auditing \& Accountability Journal, vol. 17 (n 3, 2004): 408441.

Lightbody, Margaret. "Storing and shielding: financial management behaviour in a church organization”, Accounting, Auditing \& Accountability Journal, vol. 13 (n ${ }^{\circ}$ 2, 2000): 156-167. 
Lightbody, Margaret. "On being a financial manager in a church organisation: understanding the experience”, Financial Accountability \& Management, vol. 19 ( ${ }^{\circ}$ 2, 2003): 117-138.

Lynch, John. “La Iglesia católica en América Latina, 1830-1930” in Bethell, Leslie (ed.). Historia de América Latina, Vol. 8, América Latina: cultura y sociedad, c. 18701930. Barcelona: Crítica, 2000: 65-122 (The Cambridge History of Latin America, v.c. 1870 to 1930. Cambridge: Cambridge University Press, 1986).

Martínez de Codes, Rosa María. La Iglesia católica en la América independiente. Siglo XIX. Madrid: Maphre, 1992.

Massot i Muntaner, Josep. Aproximació a la història religiosa de la Catalunya contemporània. Montserrat: Publicacions de l'Abadia, 1973.

Massot i Muntaner, Josep. Mil cent anys d'història de Montserrat, Montserrat: Publicacions de l'Abadia, 1981.

Massot i Muntaner, Josep. “L’abat Joseph Deàs i Montserrat”, Subsidia Monástica, 10, (1983): 29-48.

Meyer, Jean. “México: Revolución y reconstrucción de los años 20” in Bethell, Leslie (ed.), Historia de América Latina, vol. 9, México, América Central y el Caribe c. 18701930, Barcelona: Crítica, 2000: 146-182. (The Cambridge History of Latin America, v.c. 1870 to 1930, Cambridge university press, Cambridge, 1986).

Moliner Prada, Antonio. “Anticlericalismo y revolución liberal (1833-1874)” in La Parra López, E.; Suarez Cortina, M. (eds.) El anticlericalismo español contemporánea, Biblioteca Nueva, Madrid, 1998: 69-126.

Montero, Francisco. “La Restauración” en Manual de Historia de España, vol. 5. Madrid: Historia 16, 1990: 307-507. 
Nadal, Jordi. “La indústria cotonera” en Història Econòmica de la Catalunya contemporània, vol. 5. Barcelona: Enciclopedia Catalana, 1998: 13-85.

Palomares Ibáñez, Jesús Ma. “La recuperación económica de la Iglesia Española (18451931) in La parra, Emilio; Pradells, Jesús. Iglesia, sociedad y estado en España, Francia e Italia (ss. XVIII al XX). Alicante: Instituto de Cultura Juan Gil Albert, 1992: 153-171.

Payne, Stanley. Spanish Catholicism. Madison: University of Wisconsin Press, 1984.

Puig, T. “Anecdotari de L’Abat Deàs”, Subsidia Monástica, 10 (1983): 73-83.

Revuelta González, Manuel. La Iglesia española en el siglo XX. Madrid: Universidad Pontificia de Comillas, 2005.

Ribas Mirangels, Enric. “La España Industrial (1851-1936). Análisis económicofinanciero de la Compañía” in Doctor J. Nadal: la industrialización y el desarrollo económico de España, Barcelona: Universitat de Barcelona, 1999: 1125-1163.

Ros, Carlos. Historia de la Iglesia de Sevilla. Sevilla: Ed. Castillejo, 1992.

Rose, Mary B. Family Business. Aldershot: Edward Elgar, 1995.

Rose, Mary B. "Networks, Values and Business: The Evolution of British Family firms from the Eighteenth to the twentieth century”. Enterprises et Historie ( $\left.\mathrm{n}^{\circ} 22,1999\right)$ : 16 30.

Scranton, Philip. "Understanding the Strategies and Dynamics of Long-lived Family Firms”, Business and Economic History, vol. 21 (1992): 219-227.

Sharma, Pramodita. "An Overview of the Field of Family Business Studies: Current Status and Directions for the Future”. Family Business Review, vol. XVII, (n $\left.{ }^{\circ} 1,2004\right)$ : $1-36$.

Soler, Raimon. "Réditos algodoneros. Las cuentas de la fábrica de «la Rambla» (18401914), revisión y ampliación”, Revista de Historia Industrial, (nº 12, 1997): 205-229. 
Tafunell, Xavier. "La rentabilidad financiera de la empresa española, 1880-1981: Una estimación en perspectiva sectorial”, Revista de Historia Industrial, $\left(\mathrm{n}^{0}\right.$ 18, 2000): 71 111.

Tusell, Javier. Historia de España. 6. Siglo XX. Madrid: Historia 16, 1994.

Ullman, Joan Connelly. The Tragic Week: A Study of Anticlericalism in Spain, 18751912. Massachusetts: Cambridge, 1968.

Verdoy, Alfredo. Los bienes de los jesuitas. Madrid: Editorial Trotta, 1995.

Westhead, Paul; Cowling, Marc. "Family Firm Research: The Need for a Methodological Rethink”. Entrepreneurship Theory and Practice, Fall, (1998): 31-56.

${ }^{1}$ This article was financed by the 2006-08188/ECON and ECO2009-10739 research projects of the Ministry of Education and by the SEJ-4129 research project of the Andalusian Government. The author would like to thank the comments provided by his colleagues Antonio-Luis López Martínez, César Hornero, James Simpson, Javier Vidal and Paloma Fernández, as well as those from the anonymous reviewers of Enterprise \& History.

${ }^{2}$ Not all the orders experienced the events of the 19th century in a similar way. For example, the Jesuits were the first who suffered confiscation and they were expelled from the country with every anti-clerical attack; therefore, they adopted precaution measures very early. On the other end of the line, the Piarists were expressly excluded from all the confiscation and uncloistering processes, and the establishment of the Second Republic met them confident and trusting in a highly positive historical experience, without the need to adopt any kind of strategy.

${ }^{3}$ The Catholic Church differentiates between regular orders, whose members (the regular clergy) are subject to a particular Rule (and thus the Benedictines, 
Franciscans, Dominicans, Piarists, etc.), in contrast to the secular or diocesan clergy who is subject to the Bishop's authority in its Diocese.

4 Palomares, La recuperación; Callahan, Church; Domínguez Ortiz, Patrimonio; Cuenca, La historiografía; Ullman, The Tragic Week; Payne, Spanish Catholicism. On the Jesuits, see: Verdoy, Los bienes.

${ }^{5}$ García de Cortazar, La Iglesia, 360-361; Domínguez, Patrimonio, 120; Palomares, La recuperación, 164.

${ }^{6}$ Cárcel, La II República, 340. Worship ornaments (chalices, chasubles, stoles, etc.) were considered part of the wealth of the Church; they represented important fixed assets (mostly inherited from the past) but did not generate any income. A totally different issue is the perception of that wealth (buildings, properties, ornaments) and how this perception deeply influenced Spanish anti-clericalism. Frías Férnández, Percepciones.

7 García de Cortázar, La Iglesia, 360-361; Callahan, The Catholic, 180-181. The suspicion, still to be confirmed by scientific literature, regarding the use of tools not strictly forbidden by the law is an unresolved issue in the research on the Mexican Church during Porfirio Díaz’s government. Lynch, La Iglesia católica, 111.

${ }^{8}$ Verdoy, Los bienes.

${ }^{9}$ Verdoy, in his work Los bienes, does not analyse how the public limited companies owned by the Society of Jesus were managed or how they functioned. Literature on accounting history usually focuses in the management of the religious community - be it Catholic or not - but rarely on the companies it owned. See, for instance, Jacobs and Walker, Accounting; Lightbody, On being; Kreander, McPhail and Molyneaus, God's fund; Carmona and Ezzamel, Accounting; Lightbody, Storing. 
${ }^{10}$ The last two phases exceed the chronological frame of this article, being subsequent to the Civil War. The fifth phase covers the period of General Franco's dictatorship (1939-1975). During the first two decades of this period, National-Catholicism was instituted in Spain, an ideology that somehow relaxed during the 1960s and 1970s. The sixth phase runs parallel to the political transition and instauration of democracy in Spain, and witnesses the loss of social and political weight by the Church. Revuelta, La Iglesia; Callahan, Church, and The Catholic.

${ }^{11}$ These years are the only segment in the history of the Spanish contemporary Church before the Civil War that can be compared, despite the differences in magnitude and ideological and material intensity, to the development of the French Church during the revolution. Cuenca, La Iglesia, 15-16.

12 The popular acceptance of the orders was a key element both in Spain, during the civil war between Liberals and Carlists (absolutists who sought the support of the clergy), and in America, where the Church stood for Spain against the supporters of the independent movement (Liberals). Cárcel, El liberalismo, 153. See Martínez, La Iglesia and Lynch, La Iglesia católica.

13 This is not the right place to analyse the effects, the mechanisms used or the patrimony affected by ecclesiastical confiscations, considering that the number of references on this topic is immense. See Callahan, Church,; Bernecker, España; Cuenca, Aproximación and La Iglesia.

14 Cárcel, El liberalismo, 139. In Latin America, confiscations were effected in Argentina (1924), Bolivia (1826) or Nicaragua (1830) (Lynch, La Iglesia católica). In Mexico, the first confiscation movement was fostered by Gómez Farías and Santa Anna, following the Spanish example; however, it failed in the end due to the opposition of the conservative forces under the slogan "Religion and Privileges" 
(Martínez, La Iglesia católica). In Spain, Carlism (absolutism) was defeated, and together with it the slogan "God, Fatherland, King", on which sometimes the word “Privileges” was as well included.

${ }^{15}$ Cuenca, Aproximación, 56-57; Andrés-Gallego, La Iglesia, 99-100.

${ }^{16}$ Cuenca, Aproximación, 58.

${ }^{17}$ Moliner, Anticlericalismo, 104. Cuenca, Iglesia y burguesía, 87.

18 In Latin America, the 1860s and 1870s witnessed the end of the confiscation processes started with the Independence. Thus, Mexico experienced the nationalisation of the ecclesiastical assets (Lerdo Law of 1856); Colombia confiscated the lands of the Church following the General Mosquera Decree (1861); Venezuela suffered the confrontation between Church and State during a long period (1870-1887) with the subsequent defeat of the Church in all fronts; Chile put an end to the confiscation process in 1857 and Peru did the same between 1854 and 1856 (Cardoso, Historia Económica).

${ }^{19}$ Ros, Historia de la Iglesia. Cuenca, Aproximación, 69.

${ }^{20}$ Cuenca, Relaciones, 9.

${ }^{21}$ The Spanish Restoration and the Dictatorship of General Primo de Rivera can be compared with the long rule of Porfirio Díaz in Mexico. The description of Haber and Razo, Political, 107, can be applied to both Spaniards and Mexicans: "during that period the selection mechanism for the government was well defined and common knowledge to all: although he held presidential elections. (...) The mechanisms to manage political interaction were also clearly defined, with political authority centralised (...) through a shrewd combination of rigged elections, strategic concessions to provincial political bosses, the creation of a political machine, and outright repression". 
22 “(...) ausencia de cualquier exclusivismo y la solución de la via media para todos los problemas” (“[...] the absence of any exclusivity and the middle way solution for all problems”), Cuenca, Aproximación, 78.

${ }^{23}$ De Maeyer, Leplae and Schmiedl, Religious Institutes; Cuenca, Aproximación; Meyer, México: Revolución; Martínez, La Iglesia católica; Lynch, La Iglesia católica.

${ }^{24}$ Carr, España, 71; Cuenca, Aproximación.

${ }^{25}$ Andrés-Gallego, La política; De la Cueva, Anticlericalismo, 165-186.

${ }^{26}$ Bernecker, España.

${ }^{27}$ Montero, La Restauración, 354-362, 472-477; Díaz, La “Ley del Candado”, 145-146; Cuenca, Aproximación, 87 ff. There had been some previous attempts. "For example, in 1906 it was proposed to deprive religious orders of juridical personality to prohibit their receiving gifts or legacies (...) to prohibit minors from joining orders without consent of their parents and to give liberty to dissolve orders which included foreigners”, Branden, Church and State, 212. Callahan, Los privilegios, 30-31.

${ }^{28}$ Tusell, Historia de España, 93; Díaz, La "Ley del Candado”, 145-146; Branden, Church and State.

${ }^{29}$ During the Tragic Week in Barcelona, 21 churches and 40 convents were assaulted and burnt down. Bernecker, España, 207-209; Ullman, The Tragic Week.

30 The Second Republic and the Civil War are the periods in Spanish history on which the greatest number of studies has been made concerning any of their aspects. The reader can consult the classic texts on the History of the Church in Spain that will refer to more specific literature. For instance, see Cárcel, La II República; Andrés-Gallego, La Iglesia; Cárcel, Historia; Callahan, The Catholic; Carr, España; Tusell, Historia de España; Bernecker, España.

${ }^{31}$ Bernecker, España, 254. 
${ }^{32}$ On multi-grade schools, legislation and the attitude adopted by the Jesuits, see Frías, Iglesia y Constitución, 393 ff.

33 “(...) en particular respecto a la custodia y defensa de los bienes eclesiásticos” (“[...] in particular regarding the protection and defence of ecclesiastical properties”) said Cardinal Segura. Frías, Iglesia y Constitución, 6.

${ }^{34}$ Cabrera, Proclamación, 16.

${ }^{35}$ On the confiscation of documents to the General Vicar of Vitoria in 1931, see Verdoy, Los bienes, 85.

36 Under the Second Republic, Spain continued to suffer from the effects of the collective imagery regarding the wealth of the Church, and the belief was that the Church had invested enormous amounts of money, not in land, but in banks, industries and public services. Herr, Ensayo, 240.

${ }^{37}$ Cárcel, El liberalismo; Martínez, La Iglesia; Lynch, La Iglesia.

${ }^{38}$ Callahan, Church.

39 See the history of the Monastery of Montserrat in Massot, Mil cent; Albareda, Història; Domínguez, Patrimonio.

${ }^{40}$ Massot, L'abat, 40-41; Puig, Anecdotari.

${ }^{41}$ Council Book, March 30 ${ }^{\text {th }}$ 1883, Archives of Montserrat. All the directive positions of the Community belonged to the Council: abbot, prior, sub-prior, treasurer, administrator and the monk responsible for the novices and pupils (escolans).

${ }^{42}$ Council Book, September $13^{\text {th }} 1884$, Archives of Montserrat.

${ }^{43}$ Council Book, January $30^{\text {th }} 1890$, Archives of Montserrat.

${ }^{44}$ Council Book, October $6^{\text {th }} 1891$ and June $9^{\text {th }} 1892$, Archives of Montserrat. 
${ }^{45}$ Andrés-Gallego, La Iglesia, mentions the arrival of French Benedictines to Olza and Idiazábal, opening the possibility of transmitting the news to other monasteries belonging to the Order, like the one in Montserrat.

${ }^{46}$ Council Book, December $6^{\text {th }} 1906$, Archives of Montserrat.

${ }^{47}$ Letter of the Sancta Congregatio Episcoporum et Regularium to Abbot Deàs. Letter of Abbot Deàs, Archives of Montserrat.

${ }^{48}$ List of properties of La Agrícola Regional, S.A., Fons Larsa, box 2, Archives of Montserrat.

${ }^{49}$ To understand the Community's perspective, see Massot, Aproximació a la història religiosa de la Catalunya contemporània.

${ }^{50}$ Letters of Abbot Deàs. Archives of Montserrat.

${ }^{51}$ Albareda, Història, 107-109. Massot, “L’abat Joseph Deàs i Montserrat”.

${ }^{52}$ In Catalonia, at the end of the 19th century and the beginning of the 20th, family patrimonies in Catalonian textile industries - and this can be applied to other sectors and Spanish regions - were very much compromised by the legal figures used to define the companies. In spite of the legal change effected and the introduction of the public limited company, the strategic behaviour of Catalonian firms remained untouched because the families still linked a relevant percentage of their wealth to the development of the company. The transformation into public limited companies did not make these organisations lose their family character. See Cabana, Fàbriques and La burguesia; Fernández Roca, The adaptative ; Nadal, La indústria cotonera, 43.

53 Massot, L'abat, 44, indicates that Abbot Marcet, in directing the Monastery, was advised, among others, by his brother Aldeodat, “a naturalist and a businessman”. In addition, the letters he wrote to his second brother, Josep, reflect the exchange of 
economic information and advice on the best possibilities for investment. Letters of Abbot Marcet. Archives of Montserrat.

${ }^{54}$ Verdoy, Los bienes.

${ }^{55}$ Verdoy, Los bienes.

${ }^{56}$ Constitutional deeds of Larsa, Larsa Archive. Montserrat.

${ }^{57}$ Letters of Abbot Marcet. Archives of Montserrat.

${ }^{58}$ The documents do not explain why Abbot Marcet preferred to choose Spanish front men instead of the foreign ones recommended by Vives. Copy of the Minute Book of Larsa, Fons Larsa, box 2, Archives of Montserrat.

${ }^{59}$ The simulation of the sale does not allow finding out whether in any of the transactions money was effectively transferred between the two parts or whether it was all an accounting artifice. The documents available imply that current money was actually transferred in purchase and sale and renting operations. Particularly, in the 1931 capital expansion, the members of the Administration Board seemed in fear of not reaching total capital subscription. Therefore, the hypothesis that holds that money was effectively disbursed is valid, especially if we consider the need to keep up the fiction until the very end, even if there is no actual evidence of it. Minute Book of the Administration Board of Larsa, September $30^{\text {th }}$ 1931, Fons Larsa, box 2, Archives of Montserrat.

${ }^{60}$ Copy of the Minute Book of Larsa, Fons Larsa, box 2, Archives of Montserrat.

${ }^{61}$ List of properties of La Agrícola Regional, S.A., Fons Larsa, box 2, Archives of Montserrat.

${ }^{62}$ Council Book. June $19^{\text {th }} 1914$, Archives of Montserrat.

${ }^{63}$ Minute Book of the Administration Board of Larsa, May $26^{\text {th }} 1914$, Fons Larsa, box 2, Archives of Montserrat. 
${ }^{64}$ Minute Book of the Administration Board of Larsa, Fons Larsa, box 2. Archives of Montserrat.

${ }^{65}$ The Jesuits suffered the confiscation of almost all their patrimony during the first two years of the Second Republic. Verdoy, Los bienes, 53-54; 62 ff., $187 \mathrm{ff}$.

${ }^{66}$ Council Book, May $1{ }^{\text {st }} 1931$, Archives of Montserrat.

67 The distribution of new shares among the share-holders was as follows: Enrique Cardona Panella (80 shares, 40,000 pesetas), Salvador Mayols (80 shares, 40,000 pesetas.), Francisco Gambús (350 shares, 175,000 pesetas), Jose Pintó Badals, the Monastery’s attorney (120 shares, 60,000 pesetas), Miguel Borzo (70 shares that had previously been rejected by the Abbot, 35,000 pesetas). Extraordinary Share-Holders General Assembly, July $5^{\text {th }} 1931$. Larsa Archive, Montserrat.

${ }^{68}$ Bernecker, España, 254.

${ }^{69}$ Perpetual sale deeds. Larsa Archive, Montserrat.

${ }^{70}$ On Cultural Andorrana and the land that should have been purchased in Andorra there is no other reference in the documents examined. Therefore, we have no means to know if those lands were finally purchased. The only thing that is sure is that the Community never moved and the outbreak of the Civil War found it in Montserrat. Council Book, September $10^{\text {th }} 1931$, Archives of Montserrat.

${ }^{71}$ Minute Book of the Administration Board of Larsa, November $14^{\text {th }} 1931$.Fons Larsa, box 2. Archives of Montserrat.

${ }^{72}$ I choose the adjective “small” because those 300,000 pesetas owned by Larsa in 1913 were far from the amounts that represented the resources of other Catalonian companies, such as the cotton producers, on that same year (the least they owned was one million pesetas). See Cabana, Fàbriques and La burguesia; Fernández Roca, EBHA $12^{\text {th }}$ Annual Conference and ABH 2009 Conference; Ribas, La España Industrial. 
${ }^{73}$ The objective of longevity in family businesses is related with the fact that family firms invest in their development a percentage of the family's patrimony, which in certain cases is even the whole of it, thus compromising the economic stability of the family.

${ }^{74}$ On the role played by trust, see Scranton, Understanding. The issue of trust and religion is studied in more detail in Granovetter, The Sociology; Economic institutions and Coase revisited.

${ }^{75}$ All the data on the companies of the Catalonian cotton textile industry in this section are taken from: Cabana, Fàbriques and La burguesia; Fernández Roca, EBHA $12^{\text {th }}$ Annual Conference and ABH 2009 Conference; Ribas, La España Industrial; Soler, Réditos algodoneros.

${ }^{76}$ On Catalonian cotton textile companies, see Fernández Roca, EBHA $12^{\text {th }}$ Annual Conference and $A B H 2009$ Conference. On the definitions, characteristics and objectives of family businesses see: Colli and Rose, Families and firms; Colli, Fernandez and Rose, National Determinants; Colli, The History; Sharma, An Overview; Handler, Methodological; Westhead and Cowling, Family Firm; Channon, The Strategy; Fernández, La empresa familiar; Casson, The Economics; Rose, Family Business and Networks, Values.

771934 was a crucial year in the evolution of the Second Republic. Under the government of the CEDA (a coalition of right-wing and centre parties), some Spanish left-wing groups tried to start a revolution. This revolution temporarily triumphed only in Asturias and, after two weeks of war, it had to be suffocated by the best units of the Spanish army. 
${ }^{78}$ If the Community was frightened already in 1931 (Council Book, May $1^{\text {st }} 1931$, Archives of Montserrat), the hypothesis of a greater fear in 1934, after the October Revolution, is perfectly feasible.

79 The meeting of the Administration Board in September 1931 dealt with the assignation of the capital expansion among the shareholders in order to avoid the incorporation of new partners into Larsa. Minute Book of the Administration Board of Larsa, September 30 1931.

${ }^{80}$ The Minute Books of the Administration Board (1934-1938) are lost and we cannot prove this hypothesis in the absence of an alternative source.

${ }^{81}$ Larsa's practice was not at all new, considering that the companies' current assets were frequently financed with the shareholders' private resources, as proved by DorelFerré, Les colònies; Cabana, Fàbriques; Soler, Réditos algodoneros.

${ }^{82}$ Reserves are divided into retained earnings and contingency funds (Table 2).

${ }^{83}$ Minute Book of the Administration Board of Larsa, February $25^{\text {th }} 1919$, February 23th 1920, February $25^{\text {th }} 1926$ and Febraury 28 ${ }^{\text {th }}$ 1929. Fons Larsa, box 2. Archives of Montserrat

${ }^{84}$ On business profits in Spain, see Tafunell, La rentabilidad.

${ }^{85}$ The company's own resources are calculated by adding up capital, surplus and contingency funds.

${ }^{86}$ Council Book, February $9^{\text {th }} 1892$. Archives of Montserrat.

87 Council Book. July $5^{\text {th }}$, September $16^{\text {th }} 1913$ and January $17^{\text {th }} 1914$, Archives of Montserrat.

${ }^{88}$ Legalització de Larsa segons les llei de la Republica. Annex III. List of properties belonging to the Monastery of Montserrat, Fons Larsa, box 1, Archives of Montserrat. 